\title{
Short communication: Diet digestibility measured from fecal samples and associations with phenotypic and genetic merit for milk yield and composition
}

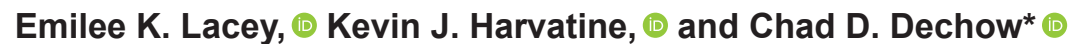 \\ Department of Animal Science, Pennsylvania State University, University Park 16802
}

\begin{abstract}
Selection for improved feed utilization is of high interest globally but is limited by the high cost of obtaining feed intake for individual cows and relies on indirect measures of feed efficiency. Supplementing selection with mechanistic measures of feed use could make selection for feed utilization more direct and effective. The objectives of this study were to evaluate fecal sampling as a method of determining digestive efficiency of individual cows and to evaluate associations of digestive efficiency with genetic and phenotypic merit for milk yield and composition. Fecal samples were obtained manually from the rectum of 90 Holstein cows in the morning, afternoon, and evening on a single date and composited across the day. The fecal samples were dried, ground, and stored. Diet and fecal neutral detergent fiber (NDF) were determined using the filter bag method, and indigestible NDF was determined in situ with a 12-d rumen incubation. Fecal NDF (60.1\%) and indigestible NDF (41.9\%) were higher than that from feed samples (14.2 and $35.9 \%$, respectively). Total-tract digestibility was calculated using the marker ratio method. Total-tract dry matter (DM) digestibility averaged $66.0 \pm 2.4 \%$ and total-tract NDF digestibility averaged $42.8 \pm 3.0 \%$. Higher milk fat percent and genetic merit for milk fat percent were associated with greater NDF and DM digestibility. Milk yield was negatively associated with NDF and DM digestibility. Fecal sampling is a feasible method to directly measure digestive efficiency, and substantial variation was observed among cows. Given significant between-cow variation and associations with milk fat percent and genetic merit for milk fat percent, potential selection for total-tract NDF digestibility estimated via fecal sampling warrants further exploration.
\end{abstract}

Key words: feed efficiency, digestibility, fecal sampling

Received August 13, 2019.

Accepted January 1, 2020.

*Corresponding author: cdd1@psu.edu

\section{Short Communication}

Selection for improved feed utilization is of high interest globally, but the cost of measuring DMI on a sufficient number of cows to facilitate genomic prediction is a challenge (Negussie et al., 2019). Predicting DMI from milk spectral data analysis or spatial imaging of feed (Seymour et al., 2019) and fewer measurements per cow on more cows (Vallimont et al., 2010) may facilitate less expensive DMI phenotypes, but this requires further development. Dry matter intake is also commonly regressed on energy sinks to derive residual feed intake (RFI) as a measure of feed efficiency; RFI is influenced by physiological factors such as protein turnover, digestive efficiency, and heat increment (Herd and Arthur, 2009; Fischer et al., 2018a) but can be influenced significantly by modeling and measurement error (Fischer et al., 2018b).

The combined effect of limited DMI observations plus indirect indicators of feed efficiency such as RFI may limit the effectiveness of selecting for improved feed utilization. Supplementing selection for RFI with mechanistic observations of energy use, such as heat loss (Hardie, 2016), could make selection for feed utilization more effective. Diet digestibility was reported to explain between 9 and $31 \%$ of variation in RFI for Holsteins fed a low-starch diet (Potts et al., 2017), and development of a low-cost method of determining digestive efficiency would facilitate selection on a mechanistic basis. The main objective of this study was to determine whether variation in apparent digestive efficiency could be detected among individual cows via fecal sampling and without observation of DMI. Additionally, we aimed to evaluate associations of digestive efficiency with milk yield, milk composition, and genetic merit for milk yield and composition.

Using a plastic sleeve, fecal samples were obtained manually from the rectum of 40 primiparous and 50 multiparous Holstein cows at the Penn State Dairy Cattle Research Center (University Park, PA) on a DHI test date (March 21, 2012). Recording of milk weights 
and component sampling occurred at both the morning (commenced at $0515 \mathrm{~h}$ ) and evening $(1700 \mathrm{~h})$ milkings. The cows averaged (mean \pm SD) $40 \pm 9 \mathrm{~kg}$ of milk/d, $177 \pm 105$ DIM, 3.7\% milk fat, and 3.0\% true milk protein and weighed $640 \pm 92 \mathrm{~kg}$. Fecal samples were collected at 3 time points starting at $0400 \mathrm{~h}$ (morning), $1130 \mathrm{~h}$ (afternoon), and $1600 \mathrm{~h}$ (evening). Cows were housed in a freestall facility and fed the same TMR delivered once in the morning. The ration was formulated for $27 \mathrm{~kg}$ of DM with $22.4 \% \mathrm{ADF}$ and $34.3 \% \mathrm{NDF}$. Ingredients were $10.7 \mathrm{~kg}$ of corn silage, $2.7 \mathrm{~kg}$ of ground corn, $2 \mathrm{~kg}$ of canola meal, $2 \mathrm{~kg}$ of cookie meal, $2 \mathrm{~kg}$ of grass haylage, $2 \mathrm{~kg}$ of alfalfa haylage, $1.5 \mathrm{~kg}$ of cooked soybeans, $1.2 \mathrm{~kg}$ of grass hay, $1.2 \mathrm{~kg}$ of cottonseed hulls, $1.1 \mathrm{~kg}$ of sugar, and $0.9 \mathrm{~kg}$ of vitamin, mineral, and additive mix. Samples of the TMR and each individual feed were also collected the same day.

The feed and fecal samples were dried at $55^{\circ} \mathrm{C}$ in a forced-air oven for $72 \mathrm{~h}$, ground in a Wiley mill through a 1-mm screen (A. H. Thomas, Philadelphia, PA), and stored in plastic bags at room temperature. The 3 fecal samples collected across the day were composited on an equal DM basis. Samples from additional cows at single time points were available but are not considered here (Panunzi, 2017). Dry matter was determined after at least $2 \mathrm{~h}$ at $105^{\circ} \mathrm{C}$ in a forced-air oven. Determination of NDF was carried out in duplicate using the Ankom A200 filter bag technique (Ankom Technology, Macedon, NY) according to Van Soest et al. (1991) using a heat-stable amylase and sodium sulfite and an acetone postrinse, and indigestible NDF (iNDF) was determined by NDF remaining after in situ incubation. Briefly, Ankom filter bags (F57; $25-\mu \mathrm{m}$ porosity; Ankom Technology) were labeled and dried at $105^{\circ} \mathrm{C}$ in a forced-air oven for a minimum of $8 \mathrm{~h}$. Approximately $0.50 \mathrm{~g}$ of ground sample was placed in each filter bag and heat sealed. The in situ incubation was replicated in 2 cows. In each cow, bags were placed into a mesh laundry bag and submerged (Huhtanen et al., 1994) in water before being tethered centrally in the rumen for $12 \mathrm{~d}(288 \mathrm{~h})$. Subsequently, the bags were removed, rinsed until the water ran clear, dried at $105^{\circ} \mathrm{C}$, and weighed to determine DM disappearance before analysis of NDF as described above. Krizsan et al. (2012) stated that derivation of iNDF from prolonged in situ incubation leads to more consistent results than in vitro methods, although a recent report indicated that in situ and in vitro methods result in similar conclusions (Bender et al., 2016).

Multiple internal markers have been applied to evaluation of feed digestibility, including iNDF, indigestible ADF, and ADL (Cochran et al., 1986). Generally, iNDF performs favorably relative to other measures of digestibility (Krizsan et al., 2012; Krizsan and Huhtanen,
2013; Morris et al., 2018) and has been used recently to demonstrate associations of digestive efficiency with RFI (Potts et al., 2017). Schalla et al. (2012) estimated apparent digestibility for pens of cows using a ratio method with iNDF as the internal marker on TMR samples and a composite of 10 or more undisturbed piles of feces; the method relies on ratios of markers rather than calculations of marker recovery. The marker ratio method was applied in the current study to samples from individual cows. Apparent total-tract DM digestibility (TTDM, \%) was calculated as

$$
1-(\text { diet iNDF, \%/feces iNDF, \%), }
$$

where diet iNDF \% is determined from either TMR sampling or the evaluation of individual diet components. Apparent total-tract NDF (TTNDF, \%) was calculated as

$$
\begin{gathered}
1-[(\text { diet iNDF, } \% \times \text { feces } \mathrm{NDF}, \%) / \\
(\text { feces iNDF, } \% \times \operatorname{diet} \mathrm{NDF}, \%)] .
\end{gathered}
$$

Derivations of TTDM and TTNDF are provided in Supplemental File S1 (https://doi.org/10.3168/jds .2019-17450). Importantly, the marker ratio method results in the same digestibility as the traditional intake method of (nutrient intake - fecal nutrient output)/ nutrient intake without analysis of feed refusals that account for sorting.

Digestibility measurements were merged with the test date records and with genetic evaluations for yield traits. Test day records from the date of fecal sampling included DIM, milk yield, fat yield and percent, protein yield and percent, SCS, and MUN. The genetic evaluations were for milk yield, fat yield and percent, and protein yield and percent. Genetic merit estimates were a mix of genomic PTA (34 cows), nongenomic PTA (55 cows), and parent average (1 cow) from the April 2019 Council on Dairy Cattle Breeding evaluation. For the 89 cows that had PTA, predicted producing ability (PPA) was available for the same traits and was a measure of the cow's predicted future performance; PPA combines breeding value, herd-sire interaction, and permanent environmental effects (Wiggans et al., 1988). Correlations of digestibility with test day and genetic merit were determined using the CORR procedure of SAS (version 9.4; SAS Institute Inc., Cary, NC) with significance declared at $P<0.05$. The reliability of genetic evaluations of yield was used as a weight in the CORR procedure to evaluate genetic merit and PPA due to the mixed source of genetic evaluations. Reliability ranged from 81 to $86 \%$ for cows with genomic PTA and from 30 to $65 \%$ for nongenomic PTA. 
Feed NDF and iNDF were similar whether diet was evaluated via TMR sampling (35.9 and $14.2 \%$, respectively) or through sampling of individual feed ingredients (32.8 and $14.6 \%$, respectively). Because diet iNDF and NDF are constants in the digestibility formulas, the correlation among cows for digestibility estimated with TMR results or with individual feed ingredients is 1.0. The practical implication is that the simpler method (likely to be TMR sampling in most instances) is sufficient if the primary goal of fecal sampling is to rank efficiency of individual cows within a group fed the same diet.

Mean TTDM, TTNDF, fecal iNDF percent, and fecal NDF percent are shown on the diagonal of Table 1 , with correlations among each digestibility measure shown below the diagonal. Total-tract DM percent was higher than TTNDF, which is expected because nonfiber diet components are more digestible. The values in Table 1 were intermediate of other estimates from the literature; a previous meta-analysis (Huhtanen et al., 2009) reported TTNDF ranging from 40.8 to $83.0 \%$ and TTDM ranging from 62.1 to $83.0 \%$. The coefficient of variation for TTNDF $(7.0 \%)$ was almost double that for TTDM $(3.6 \%)$, reflecting the larger standard deviation $(3.0 \%)$ for TTNDF than for TTDM (2.4\%) despite a lower mean. The majority of variation among diets in digestibility has previously been attributed to the percent of NDF in the diet and digestibility of NDF (Huhtanen et al., 2009). Most improvement in digestibility is likely to come through selection for improved ability to digest NDF because of the higher variability among cows for TTNDF relative to TTDM.

The marker ratio procedure provided digestibility estimates within the literature expectations and demonstrates between-cow variability. The limitations of the method are the same as those of traditional digestion studies that do not observe composition of refusals and collect multiple spot fecal samples rather than total fecal collection. Feeding behavior and feed sorting are contributors to uncertainty when measuring feed utilization. For example, a recent evaluation of feed efficiency in beef steers identified significant relationships between RFI and feed sorting behavior for steers fed a high-concentrate finishing diet (Dykier et al., 2020). Cows sorting against particles higher in NDF will have a lower proportion of iNDF in feces than predicted based on the diet formulation, which will result in an underestimate of TTDM. The accuracy of TTNDF is robust when sorting alters NDF percent of the diet provided that the relative ratio of NDF to iNDF is not heavily biased. The extent to which cows can alter this ratio when sorting feed and potential effects on TTNDF estimates warrant further exploration. The NDF:iNDF ratio is expected to be more stable in diets with low levels of high-fiber by-products, such as that fed in the current study, because both NDF and iNDF are predominantly found in the forage portion.

Correlations among TTDM, TTNDF, fecal iNDF percent, and fecal NDF percent were all significant. The calculation of TTDM assumes that all cows receive the same proportion of nondigestible DM in their feed and that all iNDF is passed through the feces. The correlation between iNDF and TTDM is thus near unity (0.99) because iNDF is the component of the formula that varies between cows when deriving TTDM. Of greater interest are the correlations of fecal NDF with TTDM $(0.65)$ and TTNDF $(-0.23)$. Cows with higher TTNDF are those that more completely digest NDF and have less NDF in the feces, resulting in the negative correlation. The positive correlation with TTDM percent largely reflects that higher fecal iNDF contributes to higher total NDF in the feces. Potentially degradable NDF in the feces can be derived as fecal NDF - fecal iNDF. Correlations of potentially degradable NDF (not shown) with TTDM $(-0.31)$ and TTNDF $(-0.97)$ indicate that more digestively efficient cows have less $\mathrm{NDF}$ in the feces that could have been digested.

Correlations of total-tract digestibility with test day records, PTA, and PPA are shown in Table 2. Higher milk fat percent was associated with higher total-tract digestibility, particularly with TTNDF. A similar association was reported between milk fat content and fiber digestibility in dairy cows in a study conducted by Oba and Allen (1999). Greater fiber digestibility is

Table 1. Mean \pm SD of total-tract DM digestibility (TTDM, \%), total-tract NDF digestibility (TTNDF, \%), fecal indigestible NDF (iNDF, \%), and fecal NDF (\%) on the diagonal plus correlations ${ }^{1}$ among each measure below the diagonal $(\mathrm{n}=90)$

\begin{tabular}{lcccc}
\hline Item & TTDM & TTNDF & Fecal iNDF & Fecal NDF \\
\hline TTDM & $66.0 \pm 2.4$ & & & \\
TTNDF & 0.57 & $42.8 \pm 3.0$ & & \\
Fecal iNDF & 0.99 & 0.54 & $41.9 \pm 3.0$ & $6.0 .1 \pm 3.8$ \\
Fecal NDF & 0.65 & -0.23 & 0.69 & 6 \\
\hline
\end{tabular}

${ }^{1}$ All correlations were significant $(P<0.05)$. 
Table 2. Correlations of total-tract DM digestibility (TTDM, \%), total-tract NDF digestibility (TTNDF, \%), fecal indigestible NDF (iNDF, \%), and fecal NDF (\%) with test-day records, PTA, and predicted producing ability (PPA)

\begin{tabular}{|c|c|c|c|c|}
\hline Item & TTNDF & TTDM & Fecal iNDF & Fecal NDF \\
\hline \multicolumn{5}{|l|}{ Test-day records } \\
\hline DIM & 0.06 & -0.05 & -0.05 & -0.13 \\
\hline Milk yield & $-0.24^{*}$ & -0.17 & -0.17 & 0.03 \\
\hline Fat yield & 0.04 & 0.01 & 0.00 & -0.02 \\
\hline Fat percent & $0.42^{* * *}$ & $0.26^{*}$ & $0.24 *$ & -0.08 \\
\hline Protein yield & $-0.26^{*}$ & $-0.22^{*}$ & $-0.22^{*}$ & -0.02 \\
\hline Protein percent & 0.09 & -0.02 & -0.04 & -0.12 \\
\hline SCS & -0.08 & -0.16 & -0.15 & -0.11 \\
\hline MUN & 0.05 & 0.17 & 0.18 & 0.17 \\
\hline \multicolumn{5}{|l|}{$\mathrm{PTA}^{1}$} \\
\hline Milk yield & -0.16 & -0.14 & -0.12 & 0.01 \\
\hline Fat yield & 0.20 & 0.08 & 0.08 & -0.06 \\
\hline Fat percent & $0.27^{*}$ & 0.16 & 0.14 & -0.06 \\
\hline Protein yield & -0.14 & -0.13 & -0.13 & -0.01 \\
\hline Protein percent & 0.06 & 0.03 & 0.01 & -0.04 \\
\hline \multicolumn{5}{|l|}{$\mathrm{PPA}^{1}$} \\
\hline Milk yield & $-0.29^{* *}$ & $-0.26^{*}$ & $-0.24^{*}$ & -0.02 \\
\hline Fat yield & 0.10 & -0.01 & 0.00 & -0.07 \\
\hline Fat percent & $0.37^{* * *}$ & $0.23^{*}$ & $0.22 *$ & -0.06 \\
\hline Protein yield & $-0.26^{*}$ & $-0.24^{*}$ & $-0.23^{*}$ & -0.03 \\
\hline Protein percent & 0.12 & 0.08 & 0.06 & -0.04 \\
\hline
\end{tabular}

${ }^{1}$ Correlations weighted by PTA reliability for yield.

${ }^{*} P<0.05 ;{ }^{*} P<0.01 ; * * * P<0.001$.

expected to be associated with a higher fat percent because greater TTNDF leads to more available nutrients (particularly acetate) for milk fat synthesis.

In contrast, test-day and future phenotypic predictions (PPA) of milk and protein yields were unfavorably associated with digestibility. The negative correlations among yield and digestibility could be attributed to rate of passage of nutrients through the digestive tract as higher yielding cows are expected to have higher feed intake and increased rate of feed passage (Moallem, 2016). This increased rate of passage corresponds to a depression in digestibility, as digesta is spending a shorter amount of time in the rumen and digestive tract.

There is broad interest in the development of selection programs to improve feed utilization, and direct emphasis on digestive efficiency could be a component of such efforts. Total-tract NDF digestibility, in particular, varied among cows, was positively correlated with fat percent and with PTA for fat percent, and was negatively correlated with milk and protein yields. Our results suggest that fecal sampling can provide a relatively simple and cost-effective method of determining variation in digestive efficiency among cows but requires validation with larger data sets.

\section{ACKNOWLEDGMENTS}

This work was supported by the USDA National Institute of Food and Agriculture (Washington, DC) and
Hatch Appropriations under Project No. PEN04691 and Accession No. 1018545. The assistance of Jennifer Vallimont, Gary Closs, and Jackie Ying (all at Penn State University, University Park, PA) in sample collection and processing is greatly appreciated. The authors have not stated any conflicts of interest.

\section{REFERENCES}

Bender, R. W., D. E. Cook, and D. K. Combs. 2016. Comparison of in situ versus in vitro methods of fiber digestion at 120 and 288 hours to quantify the indigestible neutral detergent fiber fraction of corn silage samples. J. Dairy Sci. 99:5394-5400. https://doi.org/ 10.3168/jds.2015-10258.

Cochran, R. C., D. C. Adams, J. D. Wallace, and M. L. Galyean. 1986. Predicting digestibility of different diets with internal markers: Evaluation of four potential markers. J. Anim. Sci. 63:1476-1483. https://doi.org/10.2527/jas1986.6351476x.

Dykier, K. C., J. W. Oltjen, P. H. Robinson, and R. D. Sainz. 2020. Effects of finishing diet sorting and digestibility on performance and feed efficiency in beef steers. Animal 14:59-65. https://doi.org/10 $.1017 /$ S1751731119001988.

Fischer, A., R. Delagarde, and P. Faverdin. 2018a. Identification of biological traits associated with differences in residual energy intake among lactating Holstein cows. J. Dairy Sci. 101:4193-4211. https://doi.org/10.3168/jds.2017-12636.

Fischer, A., N. Friggens, D. Berry, and P. Faverdin. 2018b. Isolating the cow-specific part of residual energy intake in lactating dairy cows using random regressions. Animal 12:1396-1404. https://doi .org/10.1017/S1751731117003214.

Hardie, L. 2016. The genetic basis and improvement of feed efficiency in lactating Holstein dairy cattle. PhD Diss. Department of Animal Science, Iowa State University, Ames.

Herd, R. M., and P. F. Arthur. 2009. Physiological basis for residual feed intake. J. Anim. Sci. 87(Suppl. 14):E64-E71. https://doi.org/ 10.2527/jas.2008-1345. 
Huhtanen, P., K. Kaustell, and S. Jaakkola. 1994. The use of internal markers to predict total digestibility and duodenal flow of nutrients in cattle given six different diets. Anim. Feed Sci. Technol. 48:211-227. https://doi.org/10.1016/0377-8401(94)90173-2.

Huhtanen, P., M. Rinne, and J. Nousiainen. 2009. A meta-analysis of feed digestion in dairy cows. 2. The effects of feeding level and diet composition on digestibility. J. Dairy Sci. 92:5031-5042. https:// doi.org/10.3168/jds.2008-1834.

Krizsan, S. J., and P. Huhtanen. 2013. Effect of diet composition and incubation time on feed indigestible neutral detergent fiber concentration in dairy cows. J. Dairy Sci. 96:1715-1726. https://doi .org/10.3168/jds.2012-5752.

Krizsan, S. J., L. Nyholm, J. Nousiainen, K. H. Südekum, and P. Huhtanen. 2012. Comparison of in vitro and in situ methods in evaluation of forage digestibility in ruminants. J. Anim. Sci. 90:3162-3173. https://doi.org/10.2527/jas.2011-4347.

Moallem, U. 2016. Future consequences of decreasing marginal production efficiency in the high yielding dairy cow. J. Dairy Sci. 99:2986-2995. https://doi.org/10.3168/jds.2015-10494.

Morris, D. L., L. R. Rebelo, P. A. Dieter, and C. Lee. 2018. Validating intrinsic markers and optimizing spot sampling frequency to estimate fecal outputs. J. Dairy Sci. 101:7980-7989. https://doi.org/ 10.3168/jds.2018-14717.

Negussie, E., T. Mehtiö, P. Mäntysaari, P. Løvendahl, E. A. Mäntysaari, and M. H. Lidauer. 2019. Reliability of breeding values for feed intake and feed efficiency traits in dairy cattle: When dry matter intake recordings are sparse under different scenarios. J. Dairy Sci. 102:7248-7262. https://doi.org/10.3168/jds.2018-16020.

Oba, M., and M. S. Allen. 1999. Evaluation of the importance of the digestibility of neutral detergent fiber from forage: Effects on dry matter intake and milk yield of dairy cows. J. Dairy Sci. 82:589596. https://doi.org/10.3168/jds.S0022-0302(99)75271-9.

Panunzi, E. K. 2017. Factors affecting feed digestibility in dairy cattle. Schreyer Honors Undergraduate Thesis. Department of Animal Science, Penn State University, University Park, PA.

Potts, S. B., J. P. Boerman, A. L. Lock, M. S. Allen, and M. J. VandeHaar. 2017. Relationship between residual feed intake and digest- ibility for lactating Holstein cows fed high and low starch diets. J. Dairy Sci. 100:265-278. https://doi.org/10.3168/jds.2016-11079.

Schalla, A., L. Meyer, Z. Meyer, S. Onetti, A. Schultz, and J. Goeser. 2012. Hot topic: Apparent total-tract nutrient digestibilities measured commercially using 120 -hour in vitro indigestible neutral detergent fiber as a marker are related to commercial dairy cattle performance. J. Dairy Sci. 95:5109-5114. https://doi.org/10.3168/ jds.2012-5650.

Seymour, D. J., A. Cánovas, C. F. Baes, T. C. S. Chud, V. R. Osborne, J. P. Cant, L. F. Brito, B. Gredler-Grandl, R. Finocchiaro, R. F. Veerkamp, Y. de Haas, and F. Miglior. 2019. Invited review: Determination of large-scale individual dry matter intake phenotypes in dairy cattle. J. Dairy Sci. 102:7655-7663. https://doi.org/ $10.3168 /$ jds.2019-16454.

Vallimont, J. E., C. D. Dechow, J. M. Daubert, M. W. Dekleva, J. W. Blum, C. M. Barlieb, W. Liu, G. A. Varga, A. J. Heinrichs, and C. R. Baumrucker. 2010. Genetic parameters of feed intake, production, body weight, body condition score, and selected type traits of Holstein cows in commercial tie-stall barns. J. Dairy Sci. 93:4892-4901. https://doi.org/10.3168/jds.2010-3189.

Van Soest, P. J., J. B. Robertson, and B. A. Lewis. 1991. Methods for dietary fiber, neutral detergent fiber, and nonstarch polysaccharides in relation to animal nutrition. J. Dairy Sci. 74:3583-3597.

Wiggans, G. R., I. Misztal, and L. D. Van Vleck. 1988. Implementation of an animal model for genetic evaluation of dairy cattle in the United States. J. Dairy Sci. 71:54-69. https://doi.org/10.1016/ S0022-0302(88)79979-8.

\section{ORCIDS}

Emilee K. Lacey (으 https://orcid.org/0000-0002-5001-6989

Kevin J. Harvatine ๑ https://orcid.org/0000-0001-6422-2647

Chad D. Dechow ํ https://orcid.org/0000-0002-9012-2807 